\title{
Micronucleus formation in mussel' (Mytilus galloprovincialis, Lamarck 1819) haemolymph, liver, and gill cells as a biomarker in the assessment of genotoxicity in İzmir Bay (Aegean Sea, Turkey)
}

\section{İzmir Körfezi (Ege Denizi, Türkiye) genotoksisitenin değerlendirilmesinde biyobelirteç olarak Midye (Mytilus galloprovincialis) hemolenf, karaciğer ve solungaç hücrelerinde mikronükleus oluşumu}

\author{
Özlem Çakal Arslan ${ }^{1 *}$ \\ Muhammet Ali Karaaslan ${ }^{5}$ \\ ${ }^{1}$ Faculty of Fisheries, Ege University, 35100 Bornova, Izmir, Turkey \\ 2 Faculty of Fisheries, Ege University, 35100 Bornova, Izmir, Turkey \\ ${ }^{3}$ Faculty of Fisheries, Ege University, 35100 Bornova, Izmir, Turkey \\ ${ }^{4}$ Faculty of Fisheries, Ege University, 35100 Bornova, Izmir, Turkey \\ ${ }^{5}$ Faculty of Fisheries, Ege University, 35100 Bornova, Izmir, Turkey
}

- Gizem Gülsever ${ }^{4}$

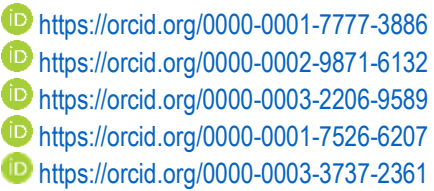

\begin{abstract}
How to cite this paper:
Çakal Arslan, Ö., Boyacıoğlu, M., Nalbantlar, B., Gülsever, G. \& Karaaslan, M. (2021). Micronucleus formation in mussel' (Mytilus galloprovincialis, Lamarck 1819) haemolymph, liver, and gill cells as a biomarker in the assessment of genotoxicity in Izmir Bay (Aegean Sea, Turkey). Ege Journal of Fisheries and Aquatic Sciences, 38(2), 189-197. DOI: 10.12714/egejfas.38.2.08
\end{abstract}

Abstract: The sea has involved a large variety of environmental contaminants and plays a crucial role in aquatic ecosystems. The Izmir Bay, which has been rapidly polluted since the 1960s, was one of the intensely polluted areas in the Mediterranean. Organic materials, hydrocarbons, metals, and pathogenic organisms that are accumulated in the region, caused high pollution and threaten health and aesthetics. Because of this, the aim of this paper was focus on to investigations of the genetic damages in mussels in Izmir Bay. Investigations of mutagenic/carcinogenic potential have an advantage in genotoxicity studies because biomarker for pollution exposure in mussel is the early detection of possible long-term effects such as cancer. Therefore, genotoxicity was the focus of the biomarker investigations in mussel during the investigations. Thus, micronucleus tests were afforded to determine genetic damage in the haemolymph, liver, and gills of Mytilus galloprovincialis living in Izmir Bay (Western Coast of Turkey). In the present study, results showed that the frequency of MN was found at a high level in station 4 and station 5 where wastes from dockyard existed contributed to the high level of pollution. The recommendation is to standardize procedures for assessment of the toxic impact of pollutants at the cellular level in aquatic species by using micronucleus assays for biomonitoring of environmental pollution.

Keywords: Micronucleus test, pollution, genotoxicity, mussel

Öz: Denizler, çok çeşitli çevresel kirleticileri içermekte ve su ekosistemlerinde önemli bir rol oynamaktadır. 1960'lı yıllardan itibaren hızla kirlenen İzmir Körfezi, Akdeniz'deki kirliliğin en yoğun olduğu alanlardan biridir. Bölgede biriken organik maddeler, hidrokarbonlar, metaller ve patojen organizmalar, estetik ve sağlık açısından yüksek derecede tehdit oluşturmaktadır. Bu nedenle, bu çalışmanın amacı Izmir Körfezi' nde bulunan midyelerde meydana gelen genetik hasarların araştırımasına odaklanmıştır. Mutajenik / karsinojenik potansiyelin araştırılması, genotoksisite çalışmalarında bir avantaj sağlamaktadır, çünkü kirliliğe maruz kalan midyelerde kullanılan, biyobelirteçler; kanser gibi olası uzun vadeli etkilerin erken saptanmasına olanak sağlamaktadır. Biyoizleme çalışmalarında; midyede yapılan biyobelirteçlerin merkezinde genotoksisite bulunmaktadır. Bu amaçla çalışmamızda; İzmir Körfezi'nde (Türkiye'nin Batı Sahili) yaşayan Mytilus galloprovincialis'in hemolenf hücrelerinde, karaciğer hücrelerinde ve solungaç hücrelerinde genetik hasarı belirlemek için mikronükleus testleri gerçekleştirilmiştir. Bu çalışmada elde edilen sonuçlar, tersaneden gelen atıkların bulunduğu 4 . istasyon ve 5 . istasyonda MN frekansının (\%o micronucleus) yüksek bulunmasına paralel olarak, kirliliğin bu bölgelerde yoğun olduğunu göstermiştir. Elde ettiğimiz verilerle, çevresel kirliliğin biyolojik olarak izlenmesi için, kirleticilerin suda yaşayan türlerde hücresel düzeyde toksik etkilerinin belirlenebilmesini, mikronükleus testlerinin kullanımının yaygınlaştırımasını ve bu yöntemlerin standartlaştırımasının gerekliliğini ortaya koymaktayız.

Anahtar kelimeler: Mikronükleus testi, kirlilik, genotoksisite, midye

\section{INTRODUCTION}

Chemicals remain a long time in the water, leading to increased environmental pollution; were caused by bioaccumulation of toxic compounds in aquatic organisms. Increases in the human population and the development of the industry are reasons for industrial pollution. All aquatic organisms are affected by chemicals in the water. However, the degree of exposure varies by species. Of these, benthic organisms are the ones with the highest degree of exposure. On the other hand, mussels and similar benthic creatures filter more water than their body weight and take them into their bodies, and all the contaminants in the water are transferred to the creatures. In this way, toxic effects of 
pollution occur. This pollution is caused by the accumulation of genotoxic and carcinogenic compounds that fixing their physiologies or causing to carcinogenesis and inhibiting the survival of the organisms in the aquatic environment. Bolognesi and Hayashi, (2011) reviewed that among the various carcinogenic and mutagenic compounds are the most dangerous as they hold their activities for several generations. Many hazardous substances exist in the water and sediment, and they are accumulated by aquatic organisms and trigger DNA or cellular damage and affect the ecosystem by the trophic chain (Izquierdo et al., 2003). It is useful to measure the number of chemical pollutants in the living body and to determine how much it is stored and taken in the environment. However, this information reflects very little biological and ecological effects, but it does not allow us to understand biochemical interactions within the organism. For this reason, it is necessary to develop Environmental Protection System or "early warning system." This system is based on the biological response of the organism in the environment against the pollutant. This is necessary to limit ecological damage. Developing this early warning system is seen as a very important points to try to determine the result if possible and to prevent cell damage at a later stage. It is not possible, not economic, and time-consuming to determine the concentration of such substances in the tissues analytically with available chemical methods. Thus, the biological methods and those based on screening for carcinogenic and mutagenic substances in the tissues of indicator organisms have gained importance (Arslan et al., 2010; 2015).

Genotoxic substances show the initial effect and even if the agent disappears, the effect continues. In fact, this effect can continue until the next generation. Genotoxic effects cause several changes that affect the morphological and chemical structure of DNA. However, the molecular biological changes that pollutants cause at first glance are on DNA. Lately, several standards in vitro genotoxicity experiments have been studied for the determination of the genotoxic potential of contaminated waters on aquatic species (Vahl et al., 1997; Harvey et al., 1999). In genetic toxicology damage at the level of chromosome play, a critical role since mutation of chromosome like chromosome breakage plays the most important role in cancer formation (Fenech, 2000). Micronuclei (MN) test is one of the most reliable techniques used to determine genetic changes in the organisms in contaminated waters and complex mixtures. In recent years, this test has been improved using many aquatic organisms (Hayashi et al., 1998, Arslan et al., 2010; 2015; Dailianis et al., 2003, Tsarpali and Dailianis, 2012). The MN assay is today applied in laboratory and field studies using hemocytes and gill cells from bivalves, mainly from the genera Mytilus. These represent 'sentinel' organisms because of their ability to survive under polluted conditions and to accumulate both organic and inorganic pollutants (Bolognesi and Fenech, 2012). Mussels are the main indicators of the health of the aquatic environment.

The Izmir Bay, which has been rapidly polluted with organic materials, hydrocarbons, metals, and pathogenic organisms accumulated in the region posed a high degree of threat to aesthetics and health. Of these basic pollutants affecting water quality, $50 \%$ were caused by industrial waste, $15 \%$ by rain, $10 \%$ by rivers, $10 \%$ by agricultural resources, and $15 \%$ by other causes. In the first evaluation, although the receiving environment of the Bay is highlighted by the intensive industrialization and rapid increase of population in the eastern and northern regions of the city, there are many natural and man-made material wastes determining the ecological status of Izmir Bay. To take the precautions of domestic and industrial pollutants mentioned in the first two articles above, all industrial wastes flowing to the Bay are treated and $70 \%$ of the domestic wastes are treated and delivered to the Bay. Because of the high pollution of Izmir Bay, biomonitoring studies are needed sensitive and practical techniques such as biomarkers (micronucleus) for detecting early warning signals for aquatic health. The MN frequency test has generally been applied to organisms where other biological effects, techniques, and contaminant levels are well documented. In general, indigenous, ecologically and economically important mollusk species could serve as indicator species for biomonitoring of environmental genotoxicity levels, for screening of Geno toxins distribution, or for assessments of genotoxicity effects from contaminant spills or effluent discharges waters.

\section{MATERIALS AND METHODS}

Izmir Bay is located in the eastern Aegean Sea between latitudes of $38^{\circ} 20^{\prime}$ and $38^{\circ} 42^{\prime} \mathrm{N}$ and longitudes of $29^{\circ} 25^{\prime}-$ $27^{\circ} 10^{\prime} \mathrm{E}$. Izmir which is the third largest city in Turkey is located at the eastern end of Izmir Bay and it has the second biggest harbor in Turkey (Sinem Atgin et al., 2000) (Figure 1). Izmir Bay, as a study area has an extensive domestic and industrial pollution load (Sinem Atgin et al., 2000). Izmir Bay has a highly disturbed environment due to the rapid increase of the population and development of industry (Sinem Atgin et al., 2000). 


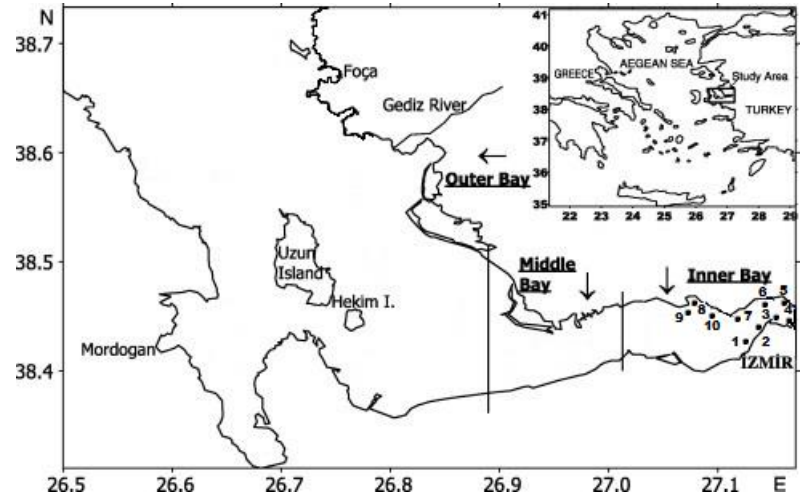

Figure 1. Study area and stations

The study area physic-chemical properties were measured as; temperature range from $13{ }^{\circ} \mathrm{C}$ to $14.5^{\circ} \mathrm{C}$, salinity range from 37.50 to $38 \mathrm{PSU}, 6.91(\mathrm{pH}), 5.5 \mathrm{mg} / \mathrm{tt}$ (dissolved oxygen)

\section{Mytilus galloprovincialis micronucleus test}

For the MN test, 15 individuals of M. galloprovincialis $6 \pm$ $3 \mathrm{~cm}$ in size obtained from harbor feet in 10 stations of Izmir Bay [Stat. 1 (Konak Pier), Stat. 2 (Üçkuyular), Stat. 3 (Göztepe), Stat. 4 (Konak), Stat. 5 (Pasaport), Stat. 6 (Alsancak), Stat. 7 (Bayraklı), Stat. 8 (Karşıyaka), Stat. 9 (Bostanlı) and Stat. 10 (Turan)], were used (Figure 1) The diagnostic criteria for micronucleus identification were used (Baršiene et al., 2006). These are, a) the micronucleus is $<1 / 3$ of the size of the main nucleus, b) micronuclei are round- or ovoid-shaped, non-refractive chromatin bodies located in the cytoplasm of the cell and can, therefore, be distinguished from artifacts, c) micronuclei are not connected to the main nuclei, and the micronuclear boundary should be distinguishable from the nuclear boundary. One thousand cells were examined per slide, with tree replicate slides per sample. The $\mathrm{MN}$ and $\mathrm{BN}$ index for the sample was determined as the mean number of micronuclei per thousand cells over the tree slides.

\section{Haemolymph}

For the MN test, haemolymph taken with a thin-tipped syringe is mixed with a fixative (3:1 methanol: acetic acid) and centrifuged at $\times 1000 \mathrm{rpm}$. The supernatant is removed after the fixation. The pellet is smeared on the slide then fixed with methanol for 10 minutes. It is allowed to dry, then stained with $5 \%$ Giemsa followed by then rinsed with distilled water and closed with a cover slide. A total of 1000 cells were counted for each individual and MN/BN frequency was calculated as $\%$ number of $\mathrm{MN}$ and $\mathrm{BN}$. A total of 45.000 cells were counting for micronucleus (MN) and binucleus $(\mathrm{BN})$ frequency from each station.

\section{Gill}

For the micronuclei test, gills dissected by scissors were fixed in acetic acid. The samples were centrifuged at x2000 rpm for 10 minutes to obtain epithelial cells shed from gill tissue by using acetic acid and pipette. The pellet obtained by this procedure is smeared on the slide and fixed by methanol. It is allowed to dry. Then, it is stained with $5 \%$ Giemsa and the slide is covered with entelan after. As mentioned before, 3 preparations were made for each individual, and 1000 cells were examined for each preparation. A total of 45.000 gill cells were counting for micronucleus (MN) and binucleus (BN) frequency from collected mussels in each station.

\section{Hepatopancreas}

For the MN test, hepatopancreas tissue was removed from 15 animals from each station and placed into Carnoy's fixative. For preparation hepatopancreas were transferred into vials containing $45 \%$ acetic acid solution for $30 \mathrm{~min}$. After that, tissues were gently minced and filtered to obtain a cell suspension. The obtained cells were smeared on a clean slide, air-dried, and fixed in Carnoy's fixative for $20 \mathrm{~min}$. Finally, they were stained with $5 \%$ Giemsa solution for 30 minutes. Three slides per animal and 45 slides per station were prepared. From each slide, 1000 cells were scored under 1000 . magnification to determine the frequencies of binucleated and micronucleated cells.

\section{Statistical analysis}

The frequency of micronuclei and binuclei in the samples obtained from Izmir Bay were calculated based on 1000 cells. Kruskal-Wallis test, Ftest and $p$ (ANOVA), and Student's t-test were used to compare nuclear abnormalities (BN and MN frequencies) between the sampling locations. All statistical analyses were performed by Statistica 6.0 statistics software.

\section{RESULTS}

The present study attempted to determine whether genotoxic potential existed in the environment of Izmir Bay using the micronuclei test of indicator organisms. The frequency of $\mathrm{BN}$ and $\mathrm{MN}$ was determined. During the examinations, other nuclear abnormalities were observed such as nuclear bats, but they were not included in the calculations since their numbers are not statistically significant. MN and BN frequencies were calculated based on microscopic examinations of slides with Haemolymph, gill, and Hepatopancreas cells of Mytilus galloprovincialis. Result data were compared statistically. 
Table 1 and Figures 2, 3 reports the results related to the application of the MN assay in biomonitoring study in the field. carried out in Izmir Bay (Turkey). Table 1 shows the nuclear abnormalities in the gills of mussels from Izmir Bay. As shown in the table. MN frequency in mussel hemolymph cells obtained from 10 stations varies between 23.7 - 38.5\% and BN frequency varies between 0.2 and $0.8 \%$. The frequencies of $\mathrm{MN}$ and $\mathrm{BN}$ were higher in mussel in the station 9 region which is highly polluted due to terrestrial inputs. Statistically, a significant difference was found between $\mathrm{MN}$ and $\mathrm{BN}$ values when micronuclei and binuclei frequencies of the locations $(p<0.05)$. According to Table 1 nuclear abnormalities in Hepatopancreas cell from sampling locations. Micronuclei averages ranged between $22.9-37.7 \%$ from the bay. MN frequencies were found at a higher level in fish from stat.8 and 10. A significant difference was found when frequencies of micronuclei found in cells were statistically compared between the stations (Figure 1). With the effect of density of pollution. the presence of $\mathrm{MN}$ in a cell increases or the formation of $\mathrm{BN}$ became observed.

Table 1. Nuclear abnormalities observed in mussels (mean \pm standard error)

\begin{tabular}{|c|c|c|c|c|c|c|c|c|c|}
\hline \multirow[b]{2}{*}{ Stations } & \multicolumn{2}{|c|}{ Gill cell $(N=1000)$} & \multirow[b]{2}{*}{ BN } & \multicolumn{2}{|c|}{ Hemolymph cell $(\mathrm{N}=1000)$} & \multirow[b]{2}{*}{ BN } & \multicolumn{3}{|c|}{ Hepatopancreas cell $(\mathrm{N}=1000)$} \\
\hline & $\mathbf{N}$ & MN & & $\mathbf{N}$ & MN & & $\mathbf{N}$ & MN & $\mathrm{BN}$ \\
\hline 1 & $966.3 \pm 6.9$ & $32.77 \pm 7.3$ & $0.97 \pm 1.9$ & $976.4 \pm 0.5$ & $28.9 \pm 0.3$ & $0.8 \pm 0.2$ & $971.8 \pm 0.6$ & $28.1 \pm 0.1$ & $0.1 \pm 0$ \\
\hline 2 & $969.57 \pm 4.4$ & $30 \pm 4.5$ & $0.43 \pm 1.0$ & $970.3 \pm 0.4$ & $29.85 \pm 0.3$ & $0.5 \pm 0.2$ & $971 \pm 1$ & $29.13 \pm 0.2$ & $0 \pm 0$ \\
\hline 3 & $974.43 \pm 5.8$ & $25.23 \pm 5.8$ & $0.33 \pm 0.7$ & $969.65 \pm 0.5$ & $24.55 \pm 0.4$ & $0.15 \pm 0.1$ & $971.1 \pm 0.5$ & $28.37 \pm 0.4$ & $0.6 \pm 0$ \\
\hline 4 & $959.2 \pm 15$ & $35.6 \pm 11.5$ & $5.27 \pm 3.9$ & $975.3 \pm 0.52$ & $23.7 \pm 0.4$ & $0.00 \pm 0.0$ & $968.7 \pm 0.8$ & $30.3 \pm 1.3$ & $0.3 \pm 0$ \\
\hline 5 & $974.03 \pm 3.8$ & $25.8 \pm 3.7$ & $0.17 \pm 0.4$ & $963.05 \pm 1.5$ & $36.35 \pm 1.3$ & $0.6 \pm 0.3$ & $976.6 \pm 0.4$ & $22.9 \pm 0.7$ & $0.4 \pm 0$ \\
\hline 6 & $965.87 \pm 11.4$ & $31.53 \pm 9.5$ & $2.43 \pm 2.6$ & $964.72 \pm 0.7$ & $34.83 \pm 0.6$ & $0.4 \pm 0.2$ & $970.03 \pm 0.5$ & $29.5 \pm 0.7$ & $0.5 \pm 0$ \\
\hline 7 & $965.23 \pm 6.2$ & $29.83 \pm 6.1$ & $5.2 \pm 2.8$ & $963.6 \pm 0.4$ & $36 \pm 0.4$ & $0.5 \pm 0.2$ & $964.5 \pm 0.6$ & $35.2 \pm 0.5$ & $0.3 \pm 0$ \\
\hline 8 & $968.77 \pm 7.2$ & $29.7 \pm 5.4$ & $1.27 \pm 2.3$ & $961.2 \pm 0.4$ & $36.05 \pm 1.1$ & $0.00 \pm 0.0$ & $961.97 \pm 0.6$ & $37.7 \pm 0.5$ & $0.3 \pm 0$ \\
\hline 9 & $968.47 \pm 7.9$ & $29.4 \pm 8.6$ & $1.27 \pm 1.5$ & $65.1 \pm 1.1$ & $38.55 \pm 0.3$ & $0.3 \pm 0.1$ & $973.1 \pm 0.9$ & $26.9 \pm 0.5$ & $0.00 \pm 0$ \\
\hline 10 & $956.87 \pm 8.5$ & $39.33 \pm 7.9$ & $3.8 \pm 2.1$ & $963.95 \pm 1.1$ & $35.25 \pm 1.0$ & $0.2 \pm 0.0$ & $963.05 \pm 1.5$ & $36.35 \pm 1.3$ & $0.1 \pm 0$ \\
\hline
\end{tabular}

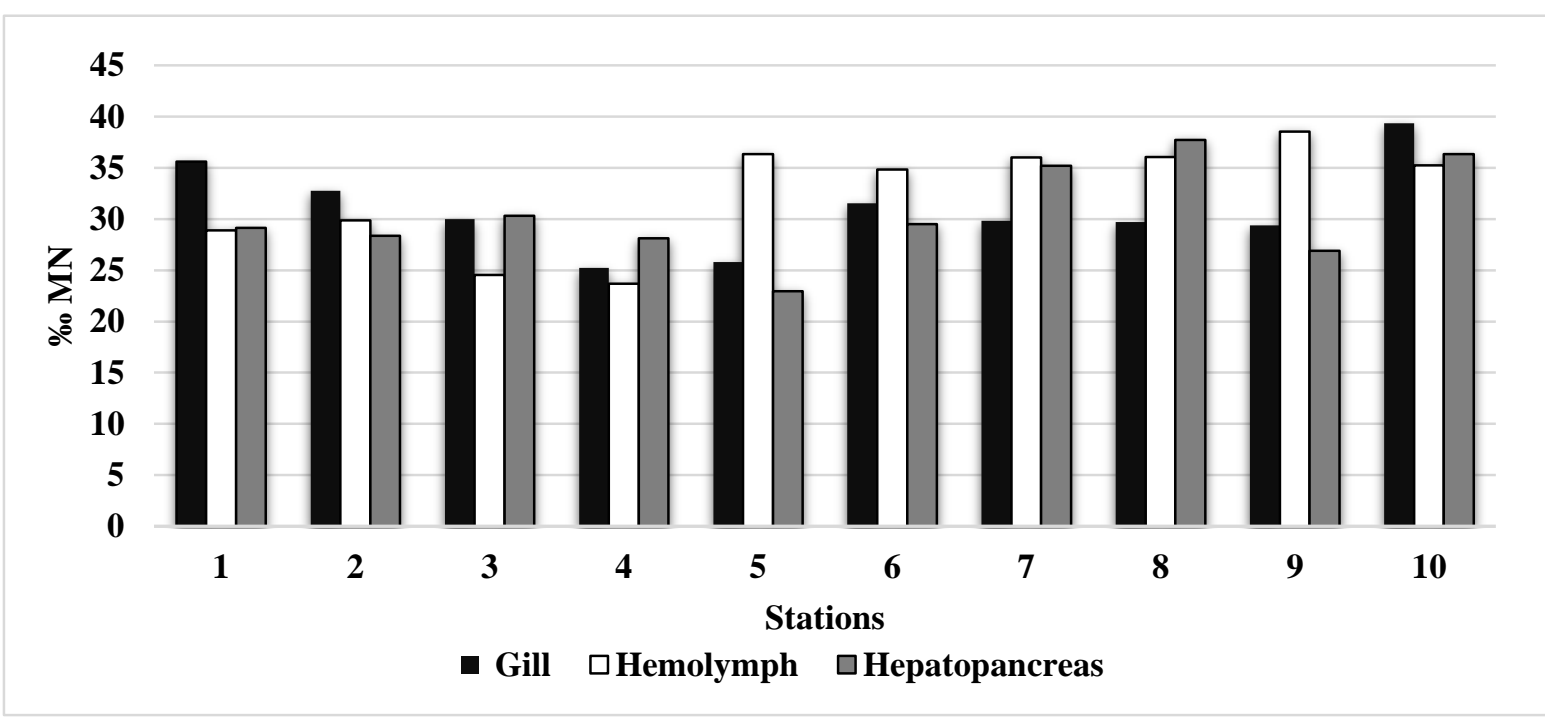

Figure 2. Distribution of MN frequencies in gill. hemolymph and hepatopancreas cells by 10 stations mussel 

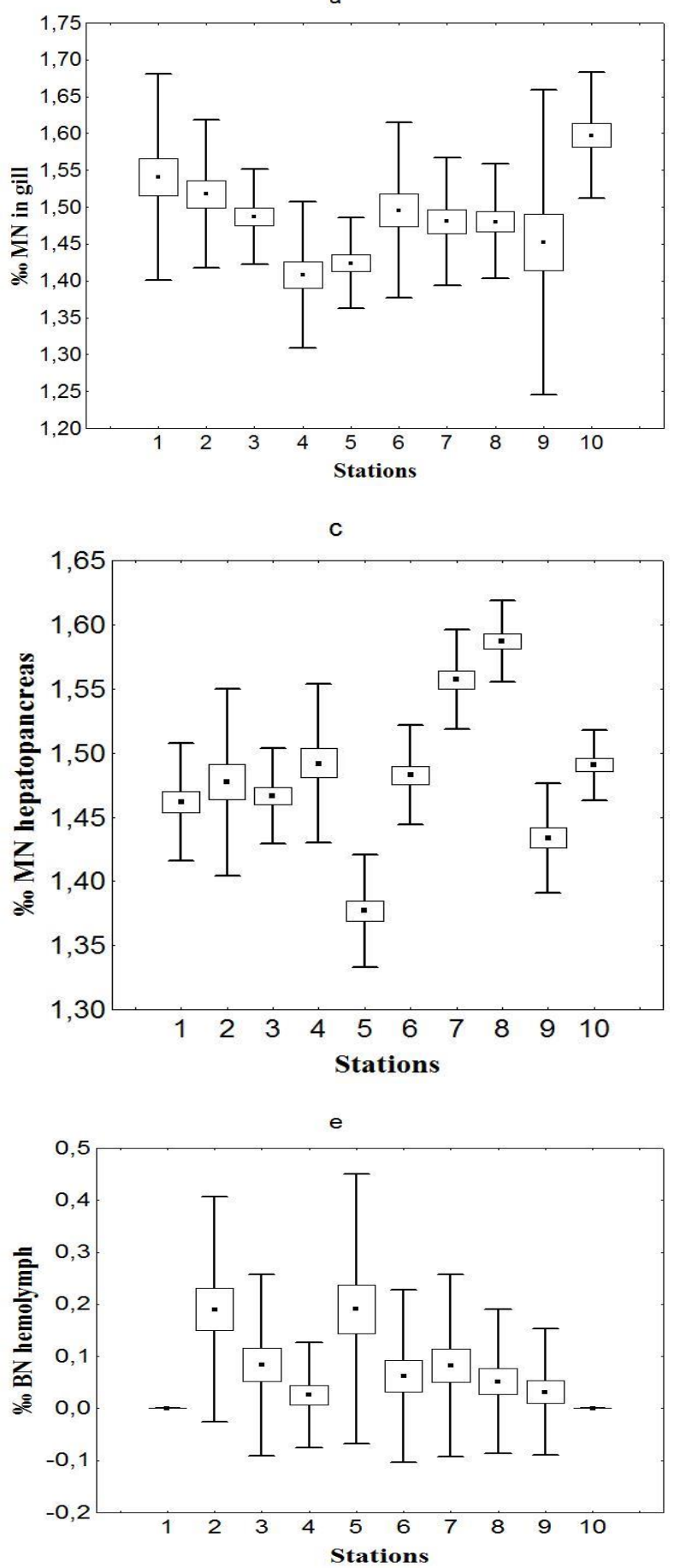

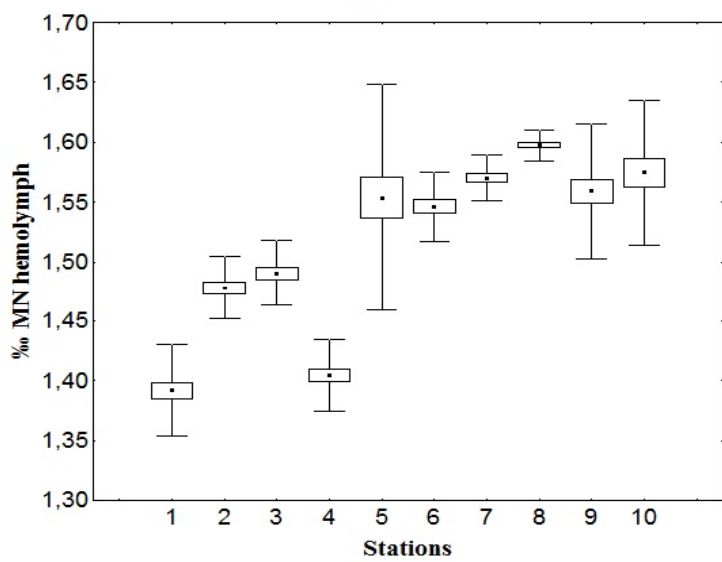

d

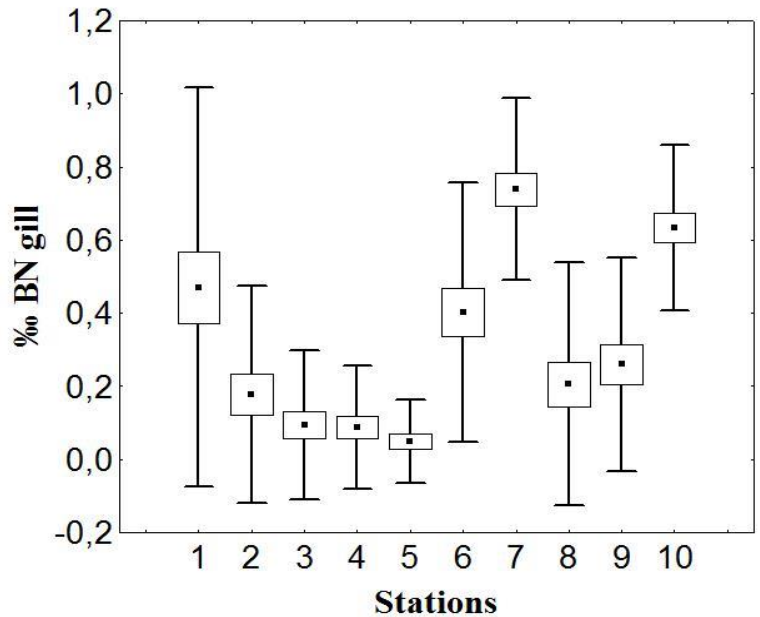

f

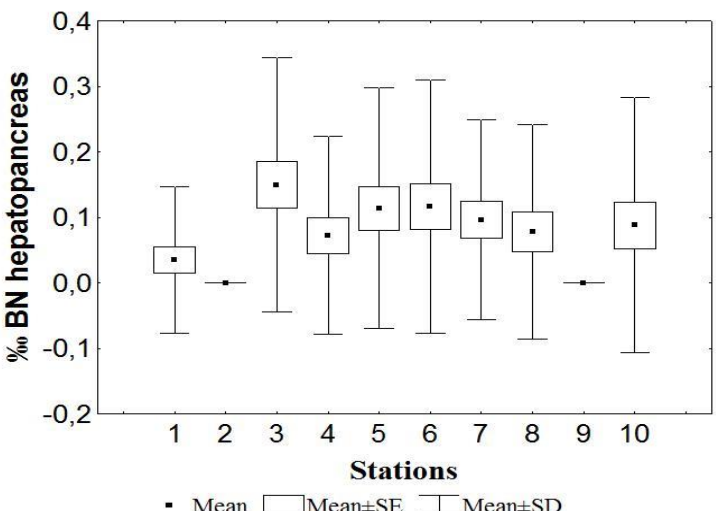

Figure 3. Statistically comparison of $\mathrm{MN}$ and $\mathrm{BN}$ frequencies between stations after logarithmic transformation. $\mathrm{KW}-\mathrm{H}$ : Kruskal-Wallis test. Ftest and $p($ ANOVA) a) gill cells $[M N$ : KW-H $(9 ; 300)=65.2608 ; p=0.0000 ; \quad F(9 ; 290)=7.3252 ; p=0.000000001]$. b) $M N$ hemolymph: $\mathrm{KW}-\mathrm{H}(9 ; 295)=204.8336 ; \mathrm{p}=00.0000 ; \mathrm{F}(9 ; 285)=75.7703 ; \mathrm{p}=00.0000$. $\mathrm{c}) \mathrm{MN}$ hepatopancreas: $\mathrm{KW}-\mathrm{H}(9 ; 300)=$ 177.8579; $p=00.0000 ; F(9 ; 290)=48.9195 ; p=00.0000$. d) BNgill: KW-H(9;300) $=109.5615 ; p=00.0000 ; F(9 ; 290)=18.9162 ; p$ $=00.0000$. e) BN hemolymph: KW-H(9;295) $=45.6443 ; p=0.0000007 ; F(9 ; 285)=5.5943 ; p=0.0000004$. f) BN hepatopancreas: $\mathrm{KW}-\mathrm{H}(9 ; 300)=29.3676 ; p=0.0006 ; \mathrm{F}(9 ; 290)=3.1736 ; p=0.0011$ 
According to examinations of mussel gills. MN frequency ranged between $25.60-39.33 \%$ and $\mathrm{BN}$ frequency between 0.17 and $5.27 \%$. As can be seen in Table 1. higher MN and BN frequencies were found in mussel gills taken from stations 10 and 4 than those taken from others. The station has four shipyard areas in which shipyard removal and repair operations are made, but it is also located near the Izmir port. As mentioned previously considering that micronuclei and binuclei frequencies vary depending on pollution one may argue that station 4 is more polluted than others. Determined MN frequencies showed statistically significant differences when micronuclei and binuclei frequencies were compared statistically between locations $(p<0.005)$. A statistically significant difference was found between $M N$ values when micronuclei frequencies of the locations $(p<0.05)$ (Figure 3). Results show that frequencies of MN in gill cells higher than hemolymph and hepatopancreas. Such studies are recommended because gill cells as well exhibit high sensitivity to the agents promoting the formation of micronuclei (Hayashi et al., 1998). Generally, gills are metabolically active tissues because their cells are under the influence of the aquatic circulation system.

\section{DISCUSSION}

In this paper, we investigate genotoxicity in the Mediterranean mussel (Mytilus galloprovincialis) from Izmir Bay (Turkey). Because the Bay is generally exposed to chemical, industrial, domestic and urban pollution whose causes a biological impact especially DNA level. Therefore, these effects were evaluated, using biomarker approaches on sentinel species. Native mussels were used to the identification of sensitiveness of specific biomarker responses. Frequencies of $\mathrm{MN}$ are an indirect marker of numeric and structural chromosomal abnormality in the cells by many agents. The aquatic organisms are highly exposed to various toxic, carcinogenic, and mutagenic agents that are caused to negative effects parallel to increasing environmental pollution. To determine the presence of mutagen / carcinogenic pollution based on cells in Izmir Bay tests were performed using the mussel hemolymph, gill, and hepatopancreas cells from 10 stations.

The Bay of Izmir has been the subject of many scientific types of research in the last 30-35 years. The research has been conducted in almost all branches of marine sciences (physical, chemical, biological, geological oceanography, marine ecology, satellite oceanography, coastal area management. etc.) (Kontas et al., 2004; Arslan et al., 2010). These monitoring studies have demonstrated the importance of eutrophication in the Gulf and that nutrient concentrations have increased from the Outer Gulf to the Central and Inner Gulf, which is due to terrestrial inputs. The concentrations of mercury $(\mathrm{Hg})$, cadmium $(\mathrm{Cd})$, chromium $(\mathrm{Cr})$, lead $(\mathrm{Pb})$, copper $(\mathrm{Cu})$, and zinc $(\mathrm{Zn})$ in sediment were measured between 1997-2007 and no significant change was observed in metal levels. It is stated that chromium $(\mathrm{Cr})$, manganese $(\mathrm{Mn})$, lead $(\mathrm{Pb})$, zinc $(\mathrm{Zn})$, copper $(\mathrm{Cu})$, and arsenic $(\mathrm{As})$ measurements made in sediment samples collected in 2009 are mostly from anthropogenic sources. Heavy metal bioaccumulation was also analyzed in our previous study (Gulsever and Arslan, 2019). In this study, Heavy metal contents of sediment samples taken from 12 stations of Izmir inner Bay were examined. The results of the analysis showed that as pollution progressed to the inner parts of the gulf. The lowest heavy metal accumulation in the sediment samples taken was at Station 2 station except manganese $(\mathrm{Pb}: 84.95$, Zn:211, Cd: 0.37, Cu: 64.48, Cr:91.8, Hg:0.326, Mn: 424, Fe: 27200.0, Al: $17000.0 \mathrm{mg} / \mathrm{kg}$ sediment). The highest concentration of $\mathrm{Pb}, \mathrm{Zn}, \mathrm{Cd}, \mathrm{Cr}$ and $\mathrm{Cu}$ for Station 10 (35.14; $138.9 ; 0.23 ; 82.4 ; 41.22 \mathrm{mg} / \mathrm{kg}$ ) while the $\mathrm{Hg}$ concentration in station $3(0.436 \mathrm{mg} / \mathrm{kg})$. $\mathrm{Mn}$ and Fe concentration station 8 $(463,29700.0 \mathrm{mg} / \mathrm{kg})$. It was observed that there was not a big change in heavy metal accumulation in sediment after the big canal project in Izmir inner bay. According to the enrichment factor calculations, Station 6 compared to all other stations the accumulation of $\mathrm{Pb}, \mathrm{Cd}$, and $\mathrm{Cu}$ elements in sediments from the region is quite high such as $6.16-5$ and 3.69. respectively. When these metal levels and MN frequencies are comparing results show that MN frequencies parallel with pollution. Weak mutagenicity was found in a study by Boyacıoğlu $(2001 ; 2004)$ on sediment samples to detect mutagenic substances in Izmir Bay. In addition, in a study showing that Izmir inner Bay sediment is not suitable for living life. Alaybey stations where the shipyard wastes are found to be high and the amount of pollution is high (Arslan et al., 2010). Based on the results of BN and MN counting on epithelial gill, hemolymph, and hepatopancreas cells from the Mytilus galloprovincialis showed that Izmir Bay has mutagenic potential. Furthermore, $t$, the difference between the stations was statistically significant $(p<0.005)$. There are no reference values because we are not sure about the situation of pollution of the area; thus, results from the mussels were evaluated to make comparisons with those from the study with the same species. (MN frequency in the control group: 0$1 \%$ ). MN assays with mussel also have shown potential as an in-situ biomonitoring tool for detecting genotoxic agents in the marine environment (Bolognesi and Fenech, 2012).

According to our previous study ( Arslan et al., 2010); examinations of mussel gills, MN frequency detected from 1.500 gill cells ranged between $30.56-89.76 \%$ and $B N$ frequency between $6.19 \%$ and $33.40 \%$. As can be reported higher $\mathrm{MN}$ and $\mathrm{BN}$ frequencies were found in mussel gills taken from stations 10 and 5 than those taken from others. As 
mentioned previously considering that micronuclei and binuclei frequencies vary depending on pollution one may argue that these two locations are more polluted than others. Micronuclei and their frequency found as a consequence of microscopic examinations in haemolymph cells of $M$. galloprovincialis from each location were showed that MN frequency ranged between $29.13 \%$ and $47.55 \%$ and $B N$ frequency between $13.73 \%$ and $29.9 \%$. When the frequencies were compared with the previous and present study (MN: 25.2-39.3 in gill, MN: 23.7-38.5 in hemolymph, and MN: 22.9-36.3 in hepatopancreas) showed that effects of pollution on induction of micronuclei at $M$. galloprovincialis decrease. Those of the gill cells with higher BN and MN frequencies indicate that gills are a better marker in micronuclei tests comparing to mussels. Statistically, a significant difference was found between $\mathrm{MN}$ and $\mathrm{BN}$ values when micronuclei and binuclei frequencies of the locations $(p$ $<0.05$ ) (Figure 3).

Bolognesi and Cirillo (2014) reported that MN assay has revealed the effects of exposure to different classes of pollutants (e.g., polycyclic aromatic hydrocarbons, heavy metals, organochlorinated compounds) showing good discrimination power and allowing the identification of genotoxicity events along a pollution gradient and facilitating recovery effects after accidental pollution events. The study of Magni et al. (2006) M. galloprovincialis was carried out in selected sites along the Gulf of Oristano (Sardinia, Italy) including a commercial port and lagoon areas characterized by intensive agricultural and mining activities. They are reported that the extent of increase of MN frequency shows changes parallel to pollution input level and composition or seasonal physiological changes. Also indicates that the use of biomarkers of DNA and chromosomal damage together with biochemical markers could provide a comprehensive indication of the impact of chemical pollutants in coastal marine ecosystems.

Klobučar et al. (2008) performed genotoxicity assessment via $\mathrm{MN}$ in Kaštela Bay and the neighboring Trogir Bay using the micronucleus test and Comet assay with mussel ( $M$. galloprovincialis) haemocytes. Native and caged mussels were included in the studies. Their results confirmed that mussels in Kaštela and Trogir Bays are affected by genotoxic contaminants. The study performed by Venier and Zampieron (2005) to determine genetic damage in M. galloprovincialis and Zosterisessor ophiocephalus, in Venice Lagoon in Italy, reported that genetic damage existed by examining MN and cellular abnormalities in haemolymph and gill tissues (5 individuals from each location). In this study, MN frequency was reported to range between $33 \%$ and $37 \%$. Furthermore, it was reported that the species naturally existing in the Lagoon were subjected to pollution-causing genetic damage. Three different species of fish were used for micronuclei tests in the monitoring study to determine environmental mutagens in different areas of the Baltic Sea by Baršiene et al. (2006). A result of the study showed that the pollutants causing genetic damage existed in the environment as understood from observation of $\mathrm{MN}$ formations. Meanwhile where more mutagenic-carcinogenic pollutants existed was determined by finding changes in $\mathrm{MN}$ frequencies among the locations. Barsiene et al. (2006) were reported that an increase was observed in micronuclei formation due to an increase in pollution. In a study by Dolcetti and Venier (2002) MN frequencies in Mediterranean mussel M. galloprovincialis was examined to determine genetic damage in both the individuals collected from its natural environment and those subjected to benzopyrene in the laboratory setting. And also, researchers were reported that $\mathrm{MN}$ formation was observed in the mussels (12 alive) collected from different areas in different periods and that micronuclei frequency found in the gills (about $8.5 \%$ ) was higher than that found in the haemolymph. And it was noted that $\mathrm{MN}$ frequency increased parallel to the increase in pollution for long years.

In the study of Izquierdo et al. (2003) micronuclei test was performed in brachial cells of Mytilus edulis to determine pollution on two different coastal areas (location of discharging domestic waste Gijon and Pueto Madryn and on locations of discharging industrial waste Puerto Madryn). According to this study results, the MN test by the mussel was shown to be sensitive in monitoring domestic pollution and proposed as a bioindicator in routine pollution investigations in coastal ecosystems. Dailianis et al. (2003), performed MN assessment in haemolymph and gills of Mytilus galloprovincialis collected from Thermaikos and Strymonikos Bays (South Greece) between July and October 2001. As a result of the $\mathrm{MN}$ assessment, either gill or haemolymph tissues showed no significant difference existed between seasons when samplings in June and October were compared.

Study Touahri et al. (2016) the mussels Mytilus galloprovincialis collected from a no contaminated site (Chaib Rasso) were transplanted during one, three, and six months at Ghazaouet harbor $(\mathrm{GH})$ areas with a strong gradient of pollution. The micronucleus test (MN) was selected to monitor the impact of contamination along with physiological indexes (condition index $\mathrm{Cl}$ and organo-somatic indexes RI and GSI). 
In this research, they have reported a negative correlation of $\mathrm{MN}$ variation in gill cells with $\mathrm{Cl}$ but a positive correlation with transplantation duration and also indicate that $\mathrm{MN}$ in the hemolymph and gills of transplanted mussels for one, three, and six months at $\mathrm{GH}$ are significantly higher than those of the reference site. However, no significant differences were noted between the three transplants at the two organs.

Harvey et al. (1999) were examined the environmental genotoxicity and cytotoxicity along the Spanish Mediterranean coast was investigated through the determination of levels of micronuclei (MN) and other nuclear abnormalities (NAs) such as nuclear buds (NB) and binucleated cells (BN) in gills of wild mussels $M$. galloprovincialis from 17 study sites. Their study obtained that the highest MN and NB levels were found in mussels from metal-polluted sites such as Cartagena (MN: 11.6\%, NB: $4.6 \%$ ) and Portman (MN: $8.0 \%$, NB: $3.5 \%$ ). Furthermore, MN levels at sites highly polluted by organic contaminants such as Barcelona, Vallcarca, Tarragona, and Valencia were lower than expected (ranging from 3.8 to $5.8 \%$ ). This data compares with the recent study result showed that Izmir Bay is highly polluted and has a mutagenic character.

The research of Kalpaxis et al., (2004) M. galloprovincialis were placed in bow nets and immersed at 3-10 m depth in a clean coastal region (reference area). Itea and two marine stations along Gulf of Patras, N. Peloponnesus Greece. One site is near the estuaries of the Glafkos River which are influenced by local industrial and urban sources (Station 1), the second site Agios Vasilios has no evident organic pollution but is enriched in metals (Station 2). One month after immersion gill cells were isolated and their micronuclei content was determined. Compared with the reference samples the micronuclei frequency values observed in mussels transplanted to Station 1 (Gulf of Patras) showed ranged between $7 \pm 1$ and $12 \pm 3$ parts per thousand (ppt). These values were significantly higher $(P<0.01)$ than those measured in specimens collected from Station 2 . Nevertheless, the micronuclei frequency in both cases was much higher than $2.4 \pm 1 \%$ recorded in reference samples. The investigators reported that MN frequency increased parallel to the increase in exposure time and concentration in the gill cells although both micronuclei and nuclear abnormalities decreased as subjection time and concentration in hemolymph increased. They noted that the difference between two types of the cell was related to cellular kinetics and cellular renewal and as a second option they noted that the difference was due to the fact that gill cells were affected by directly and continuously contaminated waters. Our results didn't show similarities with previous studies that have found lower MN frequencies in M. galloprovincialis in contaminated areas. Our results are in agreement with previous studies that have found elevated $\mathrm{MN}$ frequencies in mussel inhabiting contaminated areas. Micronuclei frequencies at gill, hemolymph, and hepatopancreas cells of $M$. galloprovincialis compared with previous studies. Izmir Bay was found polluted by mutagenic and genotoxic compounds comparing the knowledge based on scientific literature information. Aquatic ecosystems should be protected against all kinds of adverse activities which may lead to dramatic changes. Studies aimed that determining the effects of various pollutants on the organisms takes a long time and requires expensive analytic operations. More practical biological tests have many advantages such as saving time and money and obtaining reliable results and conclusions. As well as the other aquatic organisms' mussel a very suitable experimental organism for bio tests and toxicity assays.

\section{CONCLUSION}

Environmental conditions and xenobiotic exposure can be sources of stress to living organisms. Biological markers are a measurable indicator of changes that may happen at any biological level and can be considered an early warning signal of some biological or environmental state or condition. Species of the genus Mytilus sp. are systematically used as biological models for assessing the presence of pollutants in the surrounding coastal waters (Tsarpali and Dailianis, 2012). Exposure of mussels to toxicants. performed normally through direct contact of the organisms with contaminated water could result in observable structural and/or functional changes. The micronucleus (MN) test represents a sensitive indicator of both organic and inorganic mutagens and clastogens. The purpose of the present work was to compare the biological effect on the shellfish at the site assessed as being exposed to differing levels of sewage and chemical pollutants under a range of environmental conditions.

\section{ACKNOWLEDGEMENT}

The present study was supported in the context of the Scientific Research Project of Ege University Faculty of Fisheries. Hydrobiology Department (Project No: 2016/SÜF/006). 


\section{REFERENCES}

Arslan, Ö., Parlak, H., Katalay, S., Boyacioglu, M., Karaaslan, M.A. \& Guner, $H$. (2010). Detecting micronuclei frequency in some aquatic organisms for monitoring pollution of Izmir Bay (Western Turkey). Environmental Monitoring and Assessment, 165(1-4), 55-66. DOI:10.1007/s10661-009-0926-5

Arslan, Ö., Boyacioğlu, M., Parlak, H., Katalay, S. \& Karaaslan, M.A. (2015). Assessment of micronuclei induction in peripheral blood and gill cells of some fish species from Aliağa Bay Turkey. Marine Pollution Bulletin, 94(1-2),48-54. DOI:10.1016/j.marpolbul.2015.03.018

Barsiene, J., Schiedek, D., Rybakovas, A., Syvokiene, J., Kopecka, J. \& Förlin, L. (2006). Cytogenetic and cytotoxic effects in gill cells of the blue mussel Mytilus spp. from different zones of the Baltic Sea. Marine Pollution Bulletin, 53(8-9), 469-478. DOI: 10.1016/j.marpolbul.2005.11.015

Bolognesi, C. \& Hayashi, M. (2011). Micronucleus assay in aquatic animals. Mutagenesis, 26(1), 205-213. DOI:10.1093/mutage/geq073

Bolognesi, C. \& Fenech, M. (2012). Mussel micronucleus cytome assay. Nature Protocols, 7(6), 1125-1137. DOI: 10.1038/nprot.2012.043

Bolognesi, C. \& Cirillo, S. (2014). Genotoxicity biomarkers in aquatic bioindicators. Current Zoology, 60(2), 273-284. DOI: 10.1093/czoolo/60.2.273

Boyacıoğlu, M. \& Parlak, H. (2001). Mutagenicity of River Sediments Draining into Izmir Bay. Ege Journal of Fisheries and Aquatic Sciences, 18(3), 2336.

Boyacıoğlu, M. (2004). Determination of direct mutagens in sediment samples of Izmir Bay. Ege Journal of Fisheries and Aquatic Sciences, 21(1), 11-18.

Dailianis, S., Domouhtsidou, G.P., Raftopoulou, E., Kaloyianni, M. \& Dimitriadis, V.K. (2003). Evaluation of neutral red retention assay, micronucleus test, acetylcholinesterase activity, and a signal transduction molecule (cAMP) in tissues of Mytilus galloprovincialis (L.), in pollution monitoring. Marine Environmental Research, 56(4), 443-470. DOI: 10.1016/S0141-1136(03)00005-9

Dolcetti, L. \& Venier, P. (2002). Susceptibility to genetic damage and cell types in Mediterranean mussels. Marine Environmental Research, 54(35), 487-491. DOI: 10.1016/S0141-1136(02)00142-3

Fenech, M. (2000). The in vitro micronucleus technique. Mutation Research/Fundamental and Molecular Mechanisms of Mutagenesis, 455(1-2), 81-95. DOI: 10.1016/S0027-5107(00)00065-8

Gulsever G. \& Çakal Arslan, O. (2019). İzmir iç körfezi sediment kirliliğinin kimyasal ve biyolojik entegre yöntemler ile incelenmesi. 215 sayfa, Doktora Tezi, E.Ü Fen Bilimleri Enstitüsü, İzmir.

Harvey, J.S., Lyons, B.P., Page, T.S., Stewart, C. \& Parry, J.M. (1999). An assessment of the genotoxic impact of the Sea Empress oil spill by the measurement of DNA adduct levels in selected invertebrate and vertebrate species. Mutation Research/Genetic Toxicology and Environmental Mutagenesis, 441(1), 103-114. DOI: $10.1016 / \$ 1383-5718(99) 00037-6$
Hayashi, M., Ueda, T., Uyeno, K., Wada, K., Kinae, N., Saotome, K. \& Ojima, Y. (1998). Development of genotoxicity assay systems that use aquatic organisms. Mutation Research/Fundamental and Molecular Mechanisms of Mutagenesis, 399(2), 125-133. DOI: 10.1016/S0027-5107(97)00251-0

Izquierdo, J.I., Machado, G., Ayllon, F., d'Amico, V.L., Bala, L.O., Vallarino, E. \& Garcia-Vazquez, E. (2003). Assessing pollution in coastal ecosystems: a preliminary survey using the micronucleus test in the mussel Mytilus edulis. Ecotoxicology and Environmental Safety, 55(1), 24-29. DOI: 10.1016/S0147-6513(02)00041-6

Kalpaxis, D.L., Theos, C., Xaplanteri, M.A., Dinos, G.P., Catsiki, A.V. \& Leotsinidis, M. (2004). Biomonitoring of Gulf of Patras, N. Peloponnesus, Greece. Application of a biomarker suite including evaluation of translation efficiency in Mytilus galloprovincialis cells. Environmental Research, 94(2), 211-220. DOI: 10.1016/S0013-9351(03)00048-3

Klobučar, G.I.V., Štambuk, A., Hylland, K. \& Pavlica, M. (2008). Detection of DNA damage in haemocytes of Mytilus galloprovincialis in the coastal ecosystems of Kaštela and Trogir bays, Croatia. Science of the Total Environment, 405(1-3), 330-337. DOI: 10.1016/j.scitotenv.2008.05.015

Kontas, A., Kucuksezgin, F., Altay, O. \& Uluturhan, E. (2004). Monitoring of eutrophication and nutrient limitation in the Izmir Bay (Turkey) before and after Wastewater Treatment Plant. Environment International, 29(8), 1057-1062. DOI: 10.1016/S0160-4120(03)00098-9

Magni, P., De Falco, G., Falugi, C., Franzoni, M., Monteverde, M., Perrone, E. \& Bolognesi, C. (2006). Genotoxicity biomarkers and acetylcholinesterase activity in natural populations of Mytilus galloprovincialis along a pollution gradient in the Gulf of Oristano (Sardinia, western Mediterranean). Environmental Pollution, 142(1), 6572. DOI: 10.1016/j.envpol.2005.09.018

Sinem Atgin, R., El-Agha, O., Zararsiz, A., Kocataş, A., Parlak, H. \& Tuncel, G. (2000). Investigation of the sediment pollution in Izmir Bay: trace elements. Spectrochimica Acta, Part B: Atomic Spectroscopy, 55(7), 1151-1164. DOI:10.1016/S0584-8547(00)00231-7

Touahri, H.G., Boutiba, Z., Benguedda, W. \& Shaposhnikov, S. (2016). Active biomonitoring of mussels Mytilus galloprovincialis with integrated use of micronucleus assay and physiological indices to assess harbor pollution. Marine Pollution Bulletin, 110(1), 52-64.

Tsarpali, V. \& Dailianis, S. (2012). Investigation of landfill leachate toxic potency: An integrated approach with the use of stress indices in tissues of mussels. Aquatic toxicology, 124, 58-65. DOI: 10.1016/j.aquatox.2012.07.008

Vahl, H.H., Karbe, L. \& Westendorf, J. (1997). Genotoxicity assessment of suspended particulate matter in the Elbe river: Comparison of Salmonella microsome test, arabinose resistance test, and umu-test. Mutation Research - Genetic Toxicology and Environmental Mutagenesis, 394(1-3), 81-93. DOI: 10.1016/S1383-5718(97)00129-0

Venier, P. \& Zampieron, C. (2005). Evidence of genetic damage in grass gobies and mussels from the Venice lagoon. Environment International, 31(7), 1053-1064. DOI: 10.1016/j.envint.2005.05.016 